International Journal of English Language and Literature Studies

$\operatorname{ISSN}(e): 2306-0646$

$\operatorname{ISSN}(p): 2306-9910$

DOI: 10.18488 /journal.23.2018.71.15.21

Vol. 7, No. 1, 15-21

(C) 2018 AESS Publications. All Rights Reserved.

URL: www.aessweb.com

\title{
AWARENESS OF HISTORICAL BACKGROUND AS ONE OF THE FACTORS OF BETTER LANGUAGE ACQUISITION
}

Almira K

Garaeva $^{1+}$

Ildar $\mathbf{G}$

Ahmetzyanov ${ }^{2}$
'Kazan (Volga Region) Federal University, 421001, Kazan, Adoratskogo

Street, 2, 18. Russia

Email:almiragaraeva09@yandex.ruTel:+79172602372

${ }^{2}$ Kazan (Volga Region) Federal University, 420138, Fuchikov street, 12, 35. Russia

Email:ildar-rashit@yandex.ru Tel:+79274196328
Th) Check for updates

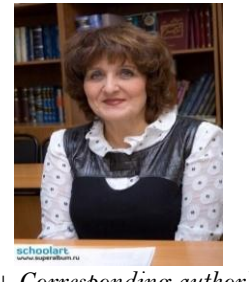

(+ Corresponding author)

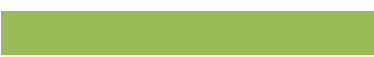

Article History

Received: 26 April 2018 Revised: 15 May 2018

Accepted: 18 May 2018

Published: 21 May 2018

\section{Keywords}

Language

History

Acquisition

Interaction

Education

Development

Knowledge.

\begin{abstract}
The article deals with the problems of language learning within the educational universities. These theme is a major one, because it is important for English learners and moreover it is connected with other aspects of the language that can be linked with students' awareness of the English language itself The essence of the issue is that the perfect acquisition of the language studied can be achieved only by learning the history of the language and the country studied as well as its relation to culture and people. The purpose of the article is to reveal a number of historical aspects of language learning, which include acquisition of material and awareness of historical background. The leading approach to the study of the problem is systematic.We suppose that it will facilitate shaping skills needed for cross-cultural communication. Any language is perceived as a social phenomenon, which comprises not only linguistic items, but also a combination of economic, behavioral and historical aspects. The materials of this paper can be recommended for use in modern practice of various educational institutions.
\end{abstract}

Contribution/ Originality: This study contributes to the existing problems in methods of foreign language teaching. This study uses new estimation technology which tends to comprise interdisciplinary approach. The paper's primary contribution is finding that language and history are closely connected

\section{INTRODUCTION}

\subsection{The Importance of the Problem}

In modern studies on methods of teaching English language an increasing attention is focused on the relation between language, history and culture.

The rapid pace of globalization and significant changes in various connections that exist between different nations and people have again outlined the importance of learning English. Today's demanding world emphasizes the necessity of having deep and profound knowledge of all foreign lamguages - due to which young specialists will be easily integrated in a fast changing society with a market economy, to be better provided with job places, to study the culture, way of life, mentality of other nations, to understand the global problems. Practical foreign language fluency began to be analyzed as an important achievement of every individual. Nowadays it has become very important to develop communicative skills because it is one of the ways of connection between people. Thus they can exchange ideas, share their achievements in technology, culture, economy, and science, a means of having 
access to the national culture which significantly affects the cultural and educational level of every person and his preferences. The prestige of the vocational training is highly valued by the relevant cross-cultural communicative awareness of Russian specialists. Well-thought out and substantiated language courses lead to the improvement of the language level of specialists with finally increases their competitiveness (Garayeva et al., 2015; Grigoryeva et al., 2015).

One of the most significant aims of Kazan Federal University is to get prepared linguistically competent specialists who will be able to socialize in multicultural communities and apply their knowledge in different spheres of contemporary life. Competence-based approach tomodern education today is one of the significant issues. Selfrealization. Self-realization of any specialist and his successful integration into the society can only be achieved by developing all major linguistic and socio-linguistic competences of a young specialist in the modern fast changing world.

All changes that occur in today's globalized world will finally lead to the necessity of understanding education as a continuous process. In order to meet the requirements and demands of the society the basic trends in the educational organizations should focus on the quality and effectiveness of the whole educational proccess (Garayeva et al., 2015; Levina et al., 2015).

It is quite obvious that many graduates of universities show not appropriable level of the English language and even those who are educated enough cannot use effectively the language in their professional communication. The rapid development of the information society demands that the professional activities of modern young professional require continuous education, commitment to everlasting modernization of one's competence.

Therefore, during training, the student should not only form the subject knowledge and skills, but also promote the development of those personal qualities that will undoubtedly enable to find new solutions to the existing problems.

Sometimes students fail to comment upon some linguistic phenomena, because they are not aware of linguohistorical aspects of the English language, customs and traditions. When people use the language some words may come in disuse or on the contrary a number of new linguistic items can be taken by different groups of people - this is one of the aspects of the language evolutions which is quite typical for any community. Language is in the centre of historical and social interaction in every society, in spite of location and time period.

\subsection{Explore Importance of the Problem}

Linguoculturology is a relatively new branch of science, which studies manifestations of culture of different nations thathave become fixed and are reflected in the language. The scientists started to learn culturology as a serious science from the beginning of the $20^{\text {th }}$ century. During their studies they mainly used various historical and social approaches. This approach is especially useful when language data alone is not able to account for some facts. Byram is of the opinion that when communicating people also exchange their social identities. In language teaching the concept of "communicative competence" takes this into account and emphasizes that language learners should acquire not just grammar forms but also have to understand what is meant under relevant language (Byram et al., 2002).

Different technologies and techniques are applied today to develop students' information competence (Garayeva et al., 2015).

When focusing on the semantic meaning of the word very often historical approach is used because it enables to trace the etymological characteristics of the lexical unit studied. Through this angle the process of learning the English language implies not only traditional study of lexicology, grammar but also the history of the English language. The formation of lingoucultural competence can be achieved through the systematic learning of language, history and culture in combination, which is a set of special skills necessary to use in practice. Mainly it is defined as ability to do what is needed .In many works the concept "competency "is explained as intellectual and personal 
ability of an individual to be able to use the language and develop various skills (Zimnyaya, 2003). She claims that the real competence is always presented by competency (Zimnyaya, 2003).

It means any culture is very important while forming linguistics concepts and there is a very close connection between the semantic meaning of the word and the linguistic symbol.

It is important to identify cultural semantics which can be obtained from the interaction of two different fields language and history. There is a strong bond between the language and the history of the country and they influence each other greatly. Subsequently many controversial problems might occur. One problem may arise when historical information of linguistic items mainly gets some implication, which is hidden. A well-known expression "French leave "means 'leave or be absent without permission '.Originally it was used as a term which described a manner ,prevalent in France in the 18th century but regarded in England as impolite , of leaving a social function without saying farewell to one's host or hostess. It is now used as illegal absence or departure, from one's place of work. From this example it is clear that only knowing the origin of the linguistic item students will manage to fully understand its meaning and use it in the language properly. Moreover sometimes the meanings of some words could be changed in course of time.

Not onlythe language and society, but also the language and history are undivided. Many factors impact the evolution of the language, mainly they are classified into internal and external ones. External (or extra-linguistic) include various social events, wars, inventions, migration of people and other major events. All of them have had not only linguistic but also psychological or the physiological aspects. To extralinguistic factors scientists refer not only main historical events, affecting social life and structure of the society, but also political and economic contacts with other people, the progress of culture, fashion and literature. All these aspects of external history determine the linguistic situation that affects the evolution of the language. The history of the country runs that at the end of the fifth and the beginning of the sixth centuries there were three Germanic tribes who invaded and settled in Britain. As all notable historic events the Anglo-Saxon migrations left their linguistic reflection on the language. The Anglo-Saxons were believed to be the pagans..Linguistic evidence of Anglo-Saxon paganism is proved by names of legendary heroes,Anglo-Saxon kings, poets of the past. The pagans worshipped nature, different gods and heavenly bodies. They usually gave people names associated with trees, animals and so on. Among the well-known and later recorded are Hengiest and Horsa (meaning "horse"), Ethelstan (precious stone), Cynewulf (leader of wolves). So that the origin of some linguistic items can be explained by some historical facts.

\subsection{Status of a Problem}

The aim of this course is to give students a clear understanding of the changes that haveoccurred in the English language throughout its development, and to help them in developing necessary scientific approach to language, which is a very important social phenomenon. So the evolution of the language is a natural but very complicated process: it is closely connected with the history of the country and also reveals the development of the society. But any social phenomenon is developing according to certain laws. There are definite internal laws of the language evolution (simplification, assimilation, analogy). They are very specific and may manifest differently. Peculiar grammar forms, peculiarities of the pronunciation of words as well as the wordstock is a result of a very long historical development, which is predetermined by a number of changes and transformations that have taken place within a more or less long periods of time. We can presume that proper understanding and use of the language can be explained and treated historically. The understanding of the laws of the development of language, the ability to explain some facts knowing the history of the language and history of the people will contribute to scientific explanation of the rules of modern English language. That is why the history of the English language course is of great importance for students. The main tasks of this course are: 
- to uncover laws governing the evolution of language as a specific system, ie such development is carried out in which the full development and interdependence of individual elements of the structure of language -phonetic, grammatical and lexical;

- to consider the relationship that exists between the language and the people who speak it. To enhance the students' master in tracing some linguistic items and to be able to explain some curious facts historically should be also trained;

- it is crucial for students as in their future activities they should be able to scientifically justify a particular linguistic phenomenon and explain it properly;

- to be able to provide basis for the relevant scientific treatment of the modification of the language the students should be offered factual material pertaining to all the aspects of the language. (phonetics, grammar, vocabularly etc)

Tracing the history of the English language in different periods, using the necessary material students are convinced that language is the product of a number of different periods of its development. So modern English is the result of a very long and gradual evolution of linguistic phenomena of the previous centuries. Some of the linguistic items can represent the remnants of ancient laws, but might be considered "wrong" and can be explained only historically. For example, the process of i-mutation which is largely presented in the formation of plural forms of nouns (man-men, foot-feet), and, therefore, be understood only by means of knowledge of the history of English language, which, therefore, is key to understanding the structure of a modern language.

\subsection{Basic Principles}

Language is a social-geographical phenomenon. There is a very deep relationship between language and society. During the long history of the development a man learns and acquires the language. We also have to focus on different dialects. People and spacious territories they occupied, their activities, the things they lived by-all these points are important for linguists and historians. What for were they ousted from their native lands? Whom did they come into contacts with? Only highlighting all these questions we will manage to provide complete and comprehensive study.

It is the study of the way in which the structure of a language changes in response to its different social functions, and the definition of what these functions are.

Language is the best manifestation of all people's actions and social behavior.

So it is important to focus on the language role in every society.

Linguohistorical competence is one of the basic components of communicative competence, the formation of which is the main goal of teaching foreign languages at the present stage. The content of the linguohistorical competence includes cognitive and communicative components. Any society needs competent professional, welltrained and well-prepared to compete in the labour market and in building a successful career. Graduates, young specialists are in great demand, those who are well -trained for corporate culture society, which will enable them to get adapted easily and quickly.

Moreover, by considering the internal structure of linguohistorical competence should be also based on a systematic approach. Linguohistorical competence of students is formed in interaction with material and spiritual values of the linguistic culture of the university in real situations of communication with different representatives.

\section{METHODOLOGICAL FRAMEWORK}

Preparing this article for comprehensive analysis a set of basic methodological principles and ideas has been used. The main focus was made on the close interaction between the language, history, culture and society. Language scholars evaluate the importance of culture in language classrooms and it has become one of the main research areas in foreign language study and teaching. There have been traced close ties between the language and the society, since the former helps to disclose the history and all main historical connections. Historical background 
of the language must be used to create awareness and understandings of historical pecularities, and written to incorporate the cultural values of those being taught. The paper discloses the importance that teachers must instruct their students on the historical background of language usage. There is some danger that students might acquire meaningless linguistic phenomena or treat incorrectly some symbols, if the whole teaching process of the language is completely disconnected with the history of the society. The whole process of teaching and learning any language can be basically spoiled by inappropriate treatment or out of the relevant cultural and historical context.

\section{RESULTS}

Intercultural communication has become a cornerstone for the further successful integration in the globalized world. So that the issue of providing urgent and indispensable conditions should be emphasized again in many Russian higher universities and other institutions to acquire a foreign language and the development of students' linguohistorical competence acquires special importance. The history of the English language provides students with some important knowledge related to the history of the country, to the existing norms and ways of life. It enables the students to disclose the spiritual values of people and their legacy. On the one hand it will stimulate students to study, increase their motivation and on the other hand it is sure to provide them with deep knowledge and better understanding of the English language. The proposed course is designed as the main subject of the course "History of the English language." The method of projects can also be here of the great use. It allows to provide an active and independent teaching and research activities of students in the study of the subject "History of the English Language". With the active involvement into the projects learners manage to revive the accumulated knowledge, to express their individual attitude to various issues and improve interpersonal skills when they work as a whole team. This type of activity demands theoretical knowledge and application of practical skills. The themes for the projects might include the following material.

1. Toponyms, their origin, basic etymological characteristics, their lexico-semantic meanings and structural elements

2. External events (wars, migration, revolutionary actions etc)

3. Antroponyms or nicknames of famous people (period of their life and time, connection with the history, influence on the society)

4. Grimm's law (essence, manifestation)

5. Important events (time, influence on the country and the language)

Work on the project is carried out at different stages. At each stage, certain tasks are solved, if necessary a teacher monitors their activities. All these projects enhance students to find some new material and enables them to treat and analyze some facts historically. They learn to work in groups, to evaluate their members' opinion and together to find solutions to the existing problems. They develop their communicative skills and alongside with it they deepen their knowledge. Intercultural communicative skills are also developed. Diagnostic tests were used to trace the effectiveness of experimental work on the formation of experimental linguoculturological competence of students.

The results of the diagnostic tests of the experiment revealed the following dynamics:

-students master their own cultural values and culture study;

-students improve their interpersonal communication.

Results can be summarized in the following way.

1. Priorities should be given to the course of the history of the English language because it covers all aspects of learning the language gives answers to many controversial issues and helps to reach the main goals of education. 
2. Linguhistorical competence is formed on the basis of more than two languages and cultures: native and non-native. The study of national culture is a basis for the formation of linguohistorical competence.

3. Psychological and pedagogical conditions of formation of linguohistorical competence of students are based on the principles of student-centered pedagogy.

4. Knowledge of language has significant educational force to influence the formation of linguohistorical competence.

\section{DISCUSSIONS}

Modern pedagogics has accumulated the necessary complex of knowledge which can be a prerequisite for the solution of the research problem (Grigoryeva et al., 2015). Any foreign language should be viewed and taught as a system of various historical, cultural, social and human factors.

However the study and theoretical analysis show that the problem of designing and implementing the language teaching content dealing with the history of the English language is an understudied field of scientific knowledge.

\section{CONCLUSION}

Any language cannot be taught as a number of linguistic items, it should be viewed and analyzed in combination of all the aspects (history, grammar, lexicology, history of the English language, country study, stylistics etc). Only knowing historical facts, the forces that drive the evolution of the language, the changes that occur in its long development learners will be able to acquire the language with all its norms and manifestations. The experimental model includes many elements: study material, built on the integration of national and regional courses and culture study, educational technology.

\section{RECOMMENDATIONS}

The materials of this article can be recommended for use in modern practice of higher institutions as well as in the system of teacher training.

Funding: This study received no specific financial support.

Competing Interests: The authors declare that they have no competing interests.

Contributors/Acknowledgement: Both authors contributed equally to the conception and design of the study.

\section{REFERENCES}

Byram, M., B. Gribkova and H. Starkey, 2002. Developing the intercultural dimension in language teaching. A practical introduction for teachers. Language policy division. Directorate of school, out - of - school and higher education. Strasbourg: DGIV Council of Europe, 7.

Garayeva, A.K., E.P. Kartashova, E.P. Nizamutdinova, Y.D. Kudakov, G.N. Akhmetzyanova, M.V. Zhuravleva and A.M. Gatiatullina, 2015. Information competence structure and content of the higher school. Mediterranean Journal of Social Sciences, 6(2 S3): 254-259. View at Google Scholar | View at Publisher

Grigoryeva, E.V., R.M. Zakirova, G.V. Solovyeva, L.S. Balashova, A.K. Garayeva and T.R. Usmanov, 2015. Features of selecting and structuring foreign language teaching content in terms of internattional component. Asian Social Science, 11(1): 380-385.View at Publisher

Levina, E.Y., Y.L. Kamasheva, F.S. Gazizova, A.K. Garayeva, J.M. Salpykova, G.F. Yusupova and N.V. Kuzmin, 2015. A process approach to management of an educational organization. Review of European Studies, 7(4): 234-240.View at Google Scholar | View at Publisher

Zimnyaya, I.A., 2003. Key competences - new paradigm of educational result. Higher Education Today, 5: 34-42.View at Google Scholar 


\section{BIBLIOGRAPHY}

Alekseeva, L.E., 2002. Optimization of the process of training the is professional-oriented dialogue of students of the faculty of international relations. PhD Thesis. St. Petersburg.

Bulatova, D.V., 1999. Theoretical foundations course in a foreign language not language high school. PhD Thesis, Moscow. pp: 521.

Dibrova, M.I. and N.M. Kabanova, 2004. Changes in the structure of the university as a result of the internationalization of education. University Management: Practice and Analysis, 2(31): 58-60.View at Google Scholar

Gorski, P.C., 2009. Intercultural education as social justice. Intercultural Education, 20(2): 87-90.View at Google Scholar $\mid$ View at Publisher

Levina, E.Y., 2012. Control of educational activities on the basis of quality management methods. Journal of Fundamental Research, $11(3): 567-671$.

Mureeva, S.V., 2001. The development of intercultural competence of future lawyers in the study of classical latin. Doctoral Dissertation, Saratov: SSU.

Nurzhanova, A., S. Burbekova and K. Mukhamadi, 2014. The development of Turkish students' Lingua cultural competence in learning Kazakh. Procedia - Social and Behavioral Sciences, 112: 532-537.View at Google Scholar $\mid$ View at Publisher

Passov, E.J., 2000. The program concept of communicative foreign language education. Moscow: Prosvescheniye.

Sheils, J., 1995. Communication skills in teaching modern languages. Strasbourg: Council of Europe Press.

Wolfram, W.A., 1969. A sociolinguistic description of detroit negro speech. Urban Language Series, No. 5. Retrieved from https:// www.linguisticsociety.org/resource/sociolinguistics. 